\title{
Trace Elements in Ambient Air at Porto Metropolitan Area-Checking for Compliance with New European Union (Eu) Air Quality Standards
}

\author{
Edgar Pintoab, Carlos Soaresb, Cristina M.C.M. Coutobc \& Agostinho Almeidab
}

Because of the scientific evidence showing that arsenic (As), cadmium (Cd), and nickel (Ni) are human genotoxic carcinogens, the European Union (EU) recently set target values for metal concentration in ambient air (As: $\left.6 \mathrm{ng} / \mathrm{m}_{3}, \mathrm{Cd}: 5 \mathrm{ng} / \mathrm{m3}, \mathrm{Ni}: 20 \mathrm{ng} / \mathrm{m} 3\right)$. The aim of our study was to determine the concentration levels of these trace elements in Porto Metropolitan Area (PMA) in order to assess whether compliance was occurring with these new EU air quality standards. Fine (PM2.5) and inhalable (PM10) air particles were collected from October 2011 to July 2012 at two different (urban and suburban) locations in PMA. Samples were analyzed for trace elements content by inductively coupled plasma-mass spectrometry (ICP-MS). The study focused on determination of differences in trace elements concentration between the two sites, and between PM2.5 and PM10, in order to gather information regarding emission sources.

Except for chromium $(\mathrm{Cr})$, the concentration of all trace elements was higher at the urban site. However, results for $\mathrm{As}, \mathrm{Cd}, \mathrm{Ni}$, and lead $(\mathrm{Pb})$ were well below the $\mathrm{EU}$ limit/target values (As: 1.49 $\left.\pm 0.71 \mathrm{ng} / \mathrm{m}_{3} ; \mathrm{Cd}: 1.67 \pm 0.92 \mathrm{ng} / \mathrm{m}_{3} ; \mathrm{Ni}: 3.43 \pm 3.23 \mathrm{ng} / \mathrm{m} 3 ; \mathrm{Pb}: 17.1 \pm 10.1 \mathrm{ng} / \mathrm{m} 3\right)$ in the worst-case scenario. Arsenic, $\mathrm{Cd}$, $\mathrm{Ni}, \mathrm{Pb}$, antimony $(\mathrm{Sb})$, selenium $(\mathrm{Se})$, vanadium $(\mathrm{V})$, and zinc $(\mathrm{Zn})$ were predominantly associated to $\mathrm{PM} .5$, indicating that anthropogenic sources such as industry and road traffic are the main source of these elements. High enrichment factors $(E F>100)$ were obtained for $\mathrm{As}, \mathrm{Cd}, \mathrm{Pb}, \mathrm{Sb}$, Se, and $\mathrm{Zn}$, further confirming their anthropogenic origin.

Air pollution is a major environmental health problem (Samet and Krewski, 2007; Costa et al., 2014). According to recent World Health Organization (WHO) estimates, in 2012 approximately 7 million people died (one out of 8 of total global deaths) as a result of air pollution exposure, confirming that air pollution is currently the world's largest single environmental health risk (WHO, 2014). Pollutants of major public health concern include sulfur dioxide $\left(\mathrm{SO}_{2}\right)$, nitrogen dioxide $\left(\mathrm{NO}_{2}\right)$, carbon monoxide $(\mathrm{CO})$, ozone $\left(\mathrm{O}_{3}\right)$, benzene, polycyclic aromatic hydrocarbons (PAH), and particulate matter (PM) (Costa et al., 2014). This has led authorities in the European Union (EU) to develop an extensive body of legislation that establishes health-based standards and objectives for these pollutants in ambient air (European Commission, 2014). Particulate matter (PM) pollution is particularly associated with serious health risks (Chang et al., 2013; Tsai and Yang, 2014). Substantial epidemiological evidence exists indicating that PM is a major health risk factor, with serious consequences on human health, by increasing the incidence of lung cancer, asthma, and cardiovascular diseases (Shrey et al., 2011; Krewski and Rainham, 2007; Craig et al., 2008; Beckerman et al., 2012). European studies on long-term exposure to PM indicate a significant direct association with mortality, particularly from cardiovascular and respiratory diseases (Pelucchi et al., 2009; Vigotti et al., 2007). The WHO has declared that PM poses the greatest air pollution threat globally (WHO, 2013).

Particulate matter (PM) is a mixture of aerosol particles (solid and liquid), with a wide range of sizes and chemical compositions (Ghio et al., 2012). PM is emitted from many anthropogenic sources, including both combustion and noncombustion sources. Important natural sources of PM are sea salt and natural resuspended dust (European Environment Agency, 2014). PM10 ("inhalable particles") refers to particles with a diameter of $10 \mu \mathrm{m}$ or less, and a limit value was set at $40 \mu \mathrm{g} / \mathrm{m} 3$ (on average over a year) for PM10 in ambient air, and entered into force in January 2005. In recent years, a class of smaller particles known as "fine particles" or PM2.5 (particles with a diameter of $2.5 \mu \mathrm{m}$ or less) was identified as of particular concern, because these particles penetrate deep into the lung, and several studies showed that PM2.5 is the air pollutant most closely linked with health problems (Tsai and Yang, 2014; Chang et al., 2013, Beckerman et al., 2012). A study from 2009 concluded that in Europe PM2.5 pollution is 
associated with more than 492,000 premature deaths, corresponding to a loss of almost 4.9 million years of life (Leeuw and Horálek, 2009). The new EU air quality directive (Directive 2008/50/EC) set a "target" value for PM2.5 at $25 \mu \mathrm{g} / \mathrm{m} 3$, which became a "limit" value in January 2015.

In recent years, the importance of chemical composition of PM, in particular its trace element content, has been increasingly recognized, in addition to the simple determination of PM mass per cubic meter, as a factor in development of air-pollutant-associated diseases (Bell and Committee, 2012; Franklinet et al., 2008; Ghio et al., 2012). Trace elements, and particularly the so-called "heavy metals," are important ambient air pollutants and are (almost exclusively) associated with PM (i.e., they are present in the solid phase of the air aerosols). Several toxicological studies examined potential mechanisms underlying the toxicity of metal-enriched particulates (Chen and Lippmann, 2009; Ghio et al., 2012; Satsangi et al., 2014; Lippmann et al., 2013). Numerous occupational studies established plausible clinical health endpoints that may be attributed to such exposures (Sarmento et al., 2008; Cakmak et al., 2014). In 1999, the EU Directive 1999/30/EC set a "limit" value for $\mathrm{Pb}$ in ambient air at $0.5 \mu \mathrm{g} / \mathrm{m} 3$. More recently, Directive 2004/107/EC, recognizing that "scientific evidence shows that arsenic, cadmium, nickel . . . are human genotoxic carcinogens" and in order "to avoid, prevent or reduce harmful effects ... on human health and the environment as a whole," also established "target values" for these elements in ambient air. Those target values were set at $6 \mathrm{ng} / \mathrm{m} 3$ for As, $5 \mathrm{ng} / \mathrm{m} 3$ for $\mathrm{Cd}$, and $20 \mathrm{ng} / \mathrm{m} 3$ for $\mathrm{Ni}$ (as the total content of these elements and compounds in the PM10 fraction). According to this directive, "Member States shall take all necessary measures not entailing disproportionate costs to ensure that, as from 31 December 2012," the target values are not exceeded.1

Heavy metals such as $\mathrm{Pb}, \mathrm{Cd}, \mathrm{Ni}$, and As are mainly emitted from anthropogenic (industrial) activities. Because of persistence and potential for long-range atmospheric transport, atmospheric emissions of heavy metals virtually affect even the most remote regions in the globe (WHO, 2007).

Lead $(\mathrm{Pb})$ is a well-known neurotoxin, and exposure to this element has been correlated with developmental and neurobehavioral effects in infants and children and elevated blood pressure in adults (Needleman, 2004). Cadmium (Cd) was categorized as a potential human carcinogen. An increased risk of lung cancer was reported following inhalation exposure in occupational settings.

Kidney and bone are also critical target organs with regard to environmental exposure (WHO, 2007; Ginsberg, 2012). Nickel (Ni) is a known human carcinogen and also produces other health effects such as skin allergies, cardiovascular effects, pulmonary fibrosis, and renal damage (Schaumloffel, 2012; Zhang et al., 2009). Arsenic (As) is actually a metalloid but is commonly included in the list of "heavy metals" based upon its toxicity. Chronic human inhalation exposure to inorganic As is associated with irritation of skin and mucous membranes with increased risk of skin and lung cancer, as well as effects on the brain and nervous system (Sun et al., 2014).

The main aims of this study were to assess whether compliance with the EU limit for $\mathrm{Pb}$ was occurring and to determine whether target values recently set for $\mathrm{As}, \mathrm{Cd}$, and $\mathrm{Ni}$ are in effect. Taking advantage of the multi-elemental capability of inductively coupled plasma-mass spectrometry (ICP-MS), several other trace elements were also measured. A health risk assessment based on the obtained concentrations was performed to assess the current importance of inhalation exposure.

\section{EXPERIMENTAL}

\section{Study Areas and Sampling}

Two distinct areas of the Porto metropolitan area (PMA), which is the second biggest urban area in Portugal with an area of almost $1600 \mathrm{~km} 2$ and a total population of more than 1.5 million inhabitants, were selected as sampling sites (SS): (i) SS1, located in an urban area, in the center of Porto, in the confluence of highly traffic streets (41॰09_19.6_N, 8.37_13.8_W); and (ii) SS2, 
located in a peripheral urban area, in Gandra, a small town about $20 \mathrm{~km}$ northeast from Porto (41.10_54.4_N, 8.26_43.6_W). A third sampling site, located in the periphery of Amarante, a small size town, outside of PMA, at $50 \mathrm{~km}$ northeast from Porto $\left(41 \cdot 16 \_10.8 \_\mathrm{N}, 8\right.$

04_10.3_W), was selected as a reference (REF) to estimate background level of trace elements in air (Figure 1).

Air sampling was performed between October 2011 to March 2012 at SS1 ( $n=24$ for PM10 and $n=22$ for PM2.5), between June and July 2012 at SS2 ( $n=17$ for PM10 and $n=13$ for PM2.5) and between April and May 2013 at REF ( $n=6$ for PM10) using an ECHO PM (Tecora, Corsico, Italy) air sampler equipped with a PM2.5 and a PM10 inlet at a flow rate of $50 \mathrm{~m} 3 / 24 \mathrm{~h}$. Periods of 24-h sampling were carried out. The samples were collected using quartz fiber filters (Munktell, Bärenstein, Germany). The filters were conditioned in a borosilicate desiccator (Duran, Mainz, Germany) for $24 \mathrm{~h}$ prior to use.

\section{Reagents and Standards}

Ultrapure water (resistivity $>18.2 \mathrm{M} \_-\mathrm{cm}$, at $25^{\circ} \mathrm{C}$ ) produced with a Milli-Q RG Ultrapure Water Purification System (Millipore, Billerica, MA) and decontaminated plastic labware (by immersion in $10 \% \mathrm{v} / \mathrm{v} \mathrm{HNO}_{3}$ during at least $24 \mathrm{~h}$ and thoroughly washed with ultrapure water) were used. Diluted $\mathrm{HNO}_{3}$ solutions were prepared from concentrated $(\geq 69 \% \mathrm{w} / \mathrm{w})$, high-purity $\mathrm{HNO}_{3}$ (TraceSELECT, Fluka, L'Isle d'Abeau Chesnes, France) with ultrapure water. Solutions for ICP-MS analysis were prepared from AccuTrace (AccuStandard, New Haven, CT) solutions: ICP-MS-200.8- CAL1R-1 (multi-element calibration standard), ICP-MS-200.8-IS-1 (internal standards), and ICP-MS-200.8-TUN-1 (tuning solution).

\section{Filter Extraction}

Filter extraction was performed according to a standard operating procedure (U.S.

Environmental Protection Agency [EPA], 2005).

Briefly, filter samples were sonicated for $3 \mathrm{~h}$ with $20 \mathrm{ml} \mathrm{4 \%} \mathrm{HNO}_{3}(\mathrm{v} / \mathrm{v})$ at $69 \circ \mathrm{C}$. Subsequently, samples were filtered through a Whatman 41 filter paper and diluted to $50 \mathrm{ml}$ with ultrapure water. Samples were kept in plastic centrifuge tubes at $4 \cdot \mathrm{C}$ until ICP-MS analysis.

\section{Analysis}

Extracts were submitted to trace element analysis by ICP-MS, performed using a VG Elemental (Winsford, UK), PlasmaQuad 3 instrument, equipped with a Meinhard type A pneumatic concentric nebulizer, a quartz water-cooled impact bead spray chamber, a standard quartz tube torch, and nickel sample and skimmer cones. Both the spray chamber and sampling interface were cooled to $10 \cdot \mathrm{C}$ by circulating water. High-purity $(99.9999 \%)$ argon (Gasin II, Leça da Palmeira, Portugal) was used as the nebulizer and plasma gas. A Gilson (Villier le Bel, France) model Minipuls 3 peristaltic pump was used for sample introduction.

Operating conditions for ICP-MS determinations were as follow: RF forward power $1350 \mathrm{~W}$; nebulizer gas flow rate $0.82 \mathrm{~L} / \mathrm{min}$; auxiliary gas flow rate $0.9 \mathrm{~L} / \mathrm{min}$; cool gas flow rate 13 $\mathrm{L} / \mathrm{min}$; dwell time $10 \mathrm{~ms}$; sweeps per replicate 100; detector, sequential; acquisition mode, peak jumping. The elemental isotopes $\left(\mathrm{m} / \mathrm{z}\right.$ ratios) $9 \mathrm{Be}, 27 \mathrm{Al}, 51 \mathrm{~V}, 52 \mathrm{Cr}, 55 \mathrm{Mn}, 59 \mathrm{Co}, 60 \mathrm{Ni},{ }_{65} \mathrm{Cu}, 66 \mathrm{Zn}$, $75 \mathrm{As}, 82 \mathrm{Se}, 95 \mathrm{Mo},{ }_{111} \mathrm{Cd}, 121 \mathrm{Sb}, 205 \mathrm{Tl}, 208 \mathrm{~Pb}, 232 \mathrm{Th}, 238 \mathrm{U}$ (as analytical masses) and $45 \mathrm{Sc}, 89 \mathrm{Y}$, $115 \mathrm{In}, 159 \mathrm{~Tb}$, and $209 \mathrm{Bi}$ (as internal standards) were monitored. $83 \mathrm{Kr}$ and $77 \mathrm{ArCl}$ were also monitored to correct for instrumental isobaric interferences. The instrument was tuned for maximum signal sensitivity and stability using $115 \mathrm{In}$ as the target isotope. Limits of detection (LOD) were calculated as the concentration corresponding to 3 times the standard deviation of 10 repeated determinations of the calibration blank signal.

Blank filters were analyzed in the same batch as filter samples, and their metal content was used to correct the metal content of samples. Results were expressed as nanograms per cubic meter, using the calculated volume of air sampled. 


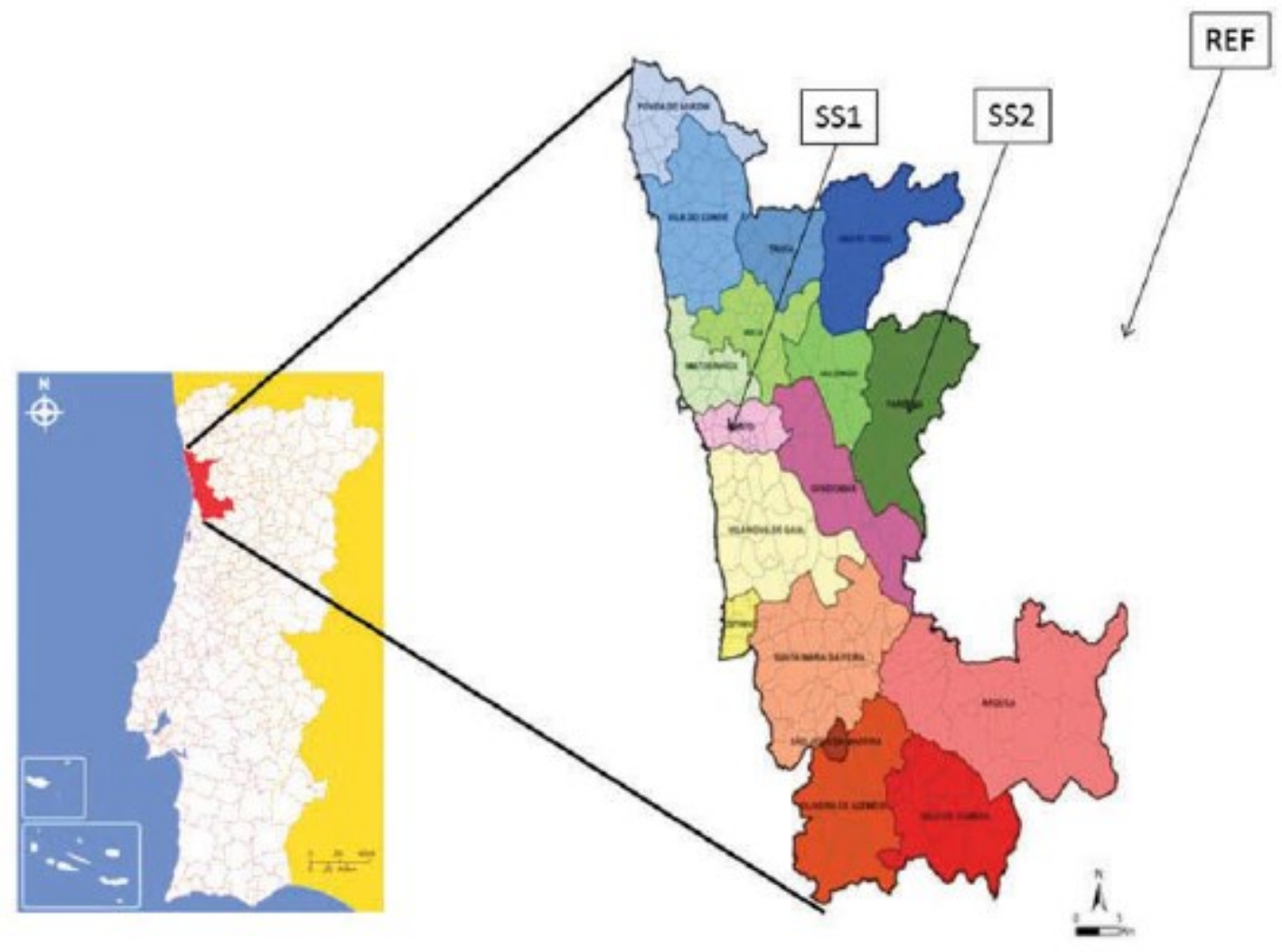

FIGURE 1. Location of the sampling sites.

\section{Analytical Quality Control}

One spike filter and one blank filter were analyzed in every set of 10 samples to determine the matrix effects and background levels from the filters, respectively. The obtained values are presented in Table 1.

\section{Enrichment Factor (EF)}

Enrichment factors (EFs) were calculated to show the degree of enrichment of a given element in PM compared to its relative abundance in crustal material. Typically, this is the first step in attempting to evaluate the importance of crustal and non-crustal sources. The enrichment factor is defined as $\mathrm{EF}=(\mathrm{X} / \mathrm{Al})$ air $/(\mathrm{X} / \mathrm{Al})$ crust, where $(\mathrm{X} / \mathrm{Al})_{\text {air }}$ and $(\mathrm{X} / \mathrm{Al})$ crust refer to the ratio of the concentration of element the $\mathrm{X}$ to that of $\mathrm{Al}$ in the air and in the average crustal material, respectively (Taylor and McLennan, 1985). Al is a common reference element in EF calculations based on its abundance and stability in the crustal surface. The crustal composition for $\mathrm{Al}$ was assumed to be $8 \%$ (w/w) (Kabata-Pendias, 2011). EFs equal to 1 indicate crustal origin for a given element, whereas EFs $>10$ indicate anthropogenic origin. 
TABLE 1. Recovery $(\%)$ and Precision ( $\%$ RSD) of the Sample Preparation Procedure

\begin{tabular}{|c|c|c|c|c|}
\hline Element & $\begin{array}{l}\text { Spike } \\
\text { levels }(\mu \mathrm{g} / \mathrm{L})\end{array}$ & Found $(\mu g / L)$ & RSD (\%) & Recovery (\%) \\
\hline \multirow[t]{2}{*}{$\mathrm{Be}$} & 0 & 0.07 & 9.6 & 98.5 \\
\hline & 1 & 1.05 & 4.7 & \\
\hline \multirow[t]{2}{*}{$\mathrm{Al}$} & 0 & 5.95 & 4.6 & 108.5 \\
\hline & 1 & 7.03 & 3.2 & \\
\hline \multirow[t]{2}{*}{ V } & 0 & 0.05 & 6.8 & 97.7 \\
\hline & 1 & 1.03 & 3.2 & \\
\hline \multirow[t]{2}{*}{$\mathrm{Cr}$} & 0 & 1.39 & 3.9 & 103.7 \\
\hline & 1 & 2.43 & 2.0 & \\
\hline \multirow[t]{2}{*}{ Mn } & 0 & 0.35 & 6.4 & 100.8 \\
\hline & 1 & 1.35 & 2.6 & \\
\hline \multirow[t]{2}{*}{ Co } & 0 & 0.02 & 9.1 & 99.4 \\
\hline & 1 & 1.01 & 2.6 & \\
\hline \multirow[t]{2}{*}{$\mathrm{Ni}$} & 0 & 0.75 & 5.6 & 107.6 \\
\hline & 1 & 1.82 & 5.8 & \\
\hline \multirow[t]{2}{*}{$\mathrm{Cu}$} & 0 & 1.26 & 5.6 & 99.1 \\
\hline & 1 & 2.25 & 2.3 & \\
\hline \multirow[t]{2}{*}{ Zn } & 0 & 2.73 & 3.9 & 97.7 \\
\hline & 1 & 3.71 & 3.4 & \\
\hline \multirow[t]{2}{*}{ As } & 0 & 0.02 & 13.3 & 95.5 \\
\hline & 1 & 0.97 & 9.0 & \\
\hline \multirow[t]{2}{*}{ Se } & 0 & 0.12 & 8.9 & 97.0 \\
\hline & 1 & 1.09 & 7.8 & \\
\hline \multirow[t]{2}{*}{ Mo } & 0 & 0.13 & 4.8 & 99.7 \\
\hline & 1 & 1.12 & 2.2 & \\
\hline \multirow[t]{2}{*}{$\mathrm{Cd}$} & 0 & 0.02 & 13.5 & 96.5 \\
\hline & 1 & 0.98 & 5.1 & \\
\hline \multirow[t]{2}{*}{$\mathrm{Sb}$} & 0 & 0.02 & 10.7 & 94.6 \\
\hline & 1 & 0.96 & 4.7 & \\
\hline \multirow[t]{2}{*}{ TI } & 0 & 0.01 & 10.1 & 98.1 \\
\hline & 1 & 0.99 & 6.4 & \\
\hline \multirow[t]{2}{*}{$\mathrm{Pb}$} & 0 & 0.20 & 5.1 & 97.4 \\
\hline & 1 & 1.17 & 4.2 & \\
\hline \multirow[t]{2}{*}{ Th } & 0 & 0.12 & 5.9 & 99.9 \\
\hline & 1 & 1.12 & 3.9 & \\
\hline \multirow[t]{2}{*}{$\mathrm{U}$} & 0 & 0.01 & 13.6 & 100.3 \\
\hline & 1 & 1.02 & 4.9 & \\
\hline
\end{tabular}

Note. Data are presented as the mean $(n=8)$.

\section{Human Health Risk Assessment}

Human health risk assessment was performed based on the average content of PMbound trace elements determined. Generally, a human health risk assessment involves four recognized steps: 1. Hazard identification: Determine which trace elements are known to produce toxicity. Al, $\mathrm{Cr}(\mathrm{III}), \mathrm{Mn}, \mathrm{V}, \mathrm{Zn}, \mathrm{Se}, \mathrm{Sb}$, and Mo are considered to induce noncarcinogenic effects, while As, $\mathrm{Cd}, \mathrm{Cr}(\mathrm{VI})$, and Ni induce carcinogenic health effects.

2. Exposure assessment: Estimate the chronic daily intake (CDI) of these trace elements. This was calculated from the following equation: 


$$
\mathrm{CDI}(\mathrm{mg} / \mathrm{kg} / \text { day })=\frac{\begin{array}{c}
\text { total dose }\left(T D, \mathrm{mg} / \mathrm{m}^{3}\right) \times \\
\text { inhlation rate }\left(I R, \mathrm{~m}^{3} / \text { day }\right)
\end{array}}{\text { body weight }(B W, \mathrm{~kg})}
$$

where TD $=C \times E$, where $C$ is the concentration of the pollutant and $E$ the deposition fraction of particles by size, given by $\mathrm{E}=-0.081+0.23 \ln \left(\mathrm{D}_{\mathrm{p}}\right)_{2}+0.23 \operatorname{sqrt}\left(\mathrm{D}_{\mathrm{p}}\right)$, where $D_{p}$ is the diameter of particles.

Inhalation rate (IR) is typically assumed to be $20 \mathrm{~m} 3 / \mathrm{d}$ and body weight (BW) to be $70 \mathrm{~kg}$ for male adults.

3. Dose-response assessment: Evaluation of the probability of health effects produced by dose of pollutant. Assuming inhalation as the single exposure route, the reference dose (RfD,

$\mathrm{mg} / \mathrm{kg} / \mathrm{d}$ ) for noncarcinogenic toxic trace elements was calculated from reference concentrations (RfC, $\mathrm{mg} / \mathrm{m} 3$ ) provided by the U.S. Environmental Protection Agency (EPA). Similarly, for carcinogenic elements the inhalation slope factor ( $\mathrm{SF}, \mathrm{mg} / \mathrm{kg} / \mathrm{d}$ ) was calculated from inhalation unit risk values (IUR, $\mathrm{mg} / \mathrm{m} 3$ ) provided by the U.S. EPA.

4. Risk characterization: Estimation of health risk by combining data from exposure and doseresponse assessment. For noncarcinogenic trace elements, risk is indicated by the hazard quotient (HQ), where $\mathrm{HQ}=\mathrm{CDI} / \mathrm{RfD}$. This HQ is an estimate of the systemic toxicity posed by a single chemical. For the systemic toxicity due to all chemicals within a single exposure the hazard index $(\mathrm{HI})$ is used, where $\mathrm{HI}_{-}=\mathrm{HQ}$. For carcinogenic trace elements, total carcinogenic risk is estimated in terms of "excess life time cancer risk" (ELCR), where ELCR $=\mathrm{CDI} \times \mathrm{SF}$ (U.S. Department of Energy [DOE], 1999).

\section{Statistical Data Analysis}

Statistical data analysis was performed with SPSS for Windows, version 22 (SPSS, Chicago, IL). The criterion for significance was set as $p<.05$.

\section{RESULTS AND DISCUSSION}

The results for the set of 18 elements (Be, Al, V, Cr, Mn, Co, Ni, Cu, Zn, As, Se, Mo, Cd, Sb, $\mathrm{Tl}, \mathrm{Pb}, \mathrm{Th}, \mathrm{U})$ determined in $\mathrm{PM} 2.5$ and $\mathrm{PM} 10$ are presented in Figures 2 and 3, respectively. Values of Be, Tl, Th, and $\mathrm{U}$ are not shown because they were always below LOD (Be: $3 \mathrm{ng} / \mathrm{L}$; TI: 4 ng/L; Th: 2 ng/L; U: 1 ng/L).

\section{Trace Elements Concentrations in Urban, Suburban, and Rural Areas}

The most abundant elements in all air samples were $\mathrm{Al}$ and $\mathrm{Zn}$, while the least abundant were Mo and Co. Overall, significantly higher trace elements content was observed in SS1 compared to SS2 and REF. The only exception was Cr, which showed a higher content in SS2 (Table 2). In particular, the content of $\mathrm{Cd}, \mathrm{Pb}$, and $\mathrm{Sb}$ in $\mathrm{SS} 1$ was severalfold higher than in the other two locations (SS2 and REF): 15.2- and 39.3- fold higher for Cd; 5.8- and 48- fold higher for Sb; and 4.8- and 9.6-fold higher for $\mathrm{Pb}$.

While some trace elements emissions are due to natural processes such as volcanic eruptions, dust storms, rock weathering, forest fires, and sea salt, most are of anthropogenic origin.

Elements such as $\mathrm{As}, \mathrm{V}, \mathrm{Co}, \mathrm{Mo}, \mathrm{Ni}, \mathrm{Se}, \mathrm{Sb}, \mathrm{Cr}$, and $\mathrm{Mn}$ are emitted during coal combustion (Xu et al., 2011), As, $\mathrm{Cr}, \mathrm{Cu}, \mathrm{Mn}$, and $\mathrm{Zn}$ are released into the atmosphere by smelting industries (González-Castanedo et al., 2014), road traffic involves the emission of a wide range of trace elements that includes $\mathrm{Pb}, \mathrm{Cu}, \mathrm{Zn}$, and $\mathrm{Cd}$ (Gunawardena et al., 2012), and $\mathrm{Ni}$ and $\mathrm{V}$ are tracers for oil combustion (Peltier et al., 2009; Peltier and Lippmann, 2010). Porto city (SS1) is the largest urban center of PMA and the second largest city in Portugal.

Within the Porto urban area there are several industries of particular significance, such as a refinery, a power plant, a steel factory, manufacturing industries, an international airport, a large seaport infrastructure, and a large co-generation urban solid waste incineration facility. These facilities are well-known important sources of air pollution. Thus, the higher content of trace 
elements, especially $\mathrm{Cd}, \mathrm{Sb}$, and $\mathrm{Pb}$, in $\mathrm{SS} 1$ might be attributed to these industrial activities and traffic emissions. It is well established that $\mathrm{Se}$ and As are tracers for coal combustion, while $\mathrm{Ni}$ and $\mathrm{V}$ are tracers for oil combustion. The concentrations of both Se and As, as measured in PM10, were higher than those at the reference site (Table 2). In addition, most of the Se and As was found to be associated with PM2.5 (Table 3). This suggests that coal combustion is a major source of urban and suburban PM2.5. With regard to Ni, concentrations in SS1 and SS2 are essentially similar, while Ni concentrations, as measured in PM10, at the reference site are lower.

In contrast, for $\mathrm{V}$, the concentrations at SS1 are higher than those at SS2 (Figures 2 and 3). $\mathrm{The} \mathrm{Ni} / \mathrm{V}$ ratio is higher when from combustion sources relying on residual oil or bunker oil than on fuel oil for space heating or motor vehicle fuels (Peltier et al., 2009; Peltier and Lippmann, 2010). Data suggest that on-board heavy oil combustion in the seaport at Porto may be a significant source of PM2.5 in Porto.

As expected, $\mathrm{Al}$ was the most abundant trace element in PM10 in SS1 since it is the major crustal constituent of airborne soil, and road dust is known to make an important contribution to coarse aerosol (Gugamsetty et al.,

2012).

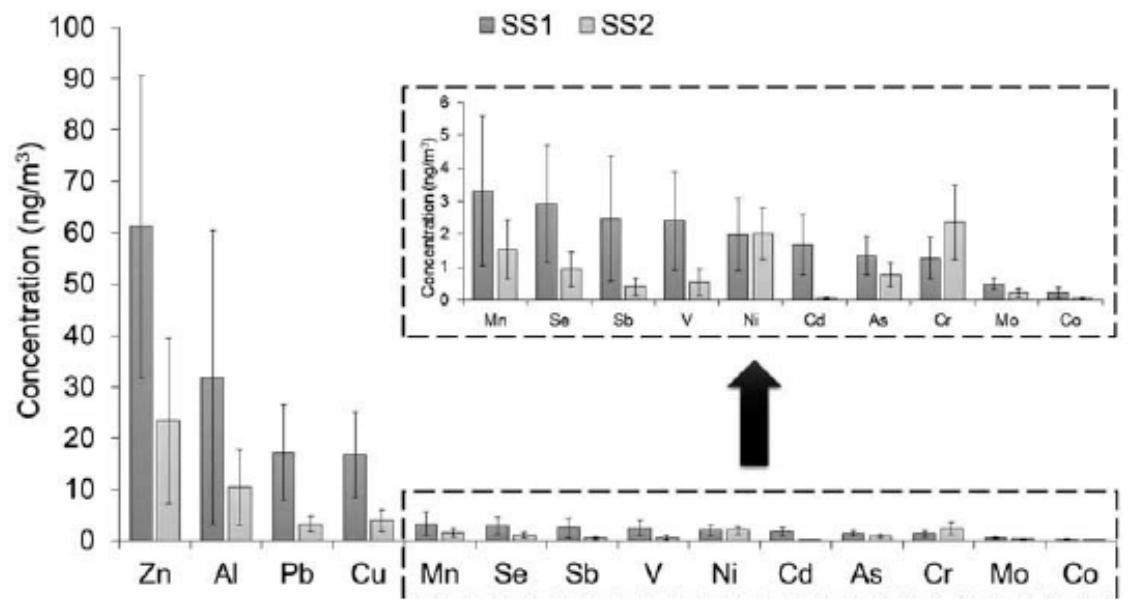

FIGURE 2. Concentration of $\mathrm{PM}_{2.5}$-bound trace elements $\left(\mathrm{ng} / \mathrm{m}^{3}\right.$ ) in ambient air at SS1 (urban site) and SS2 (suburban site).

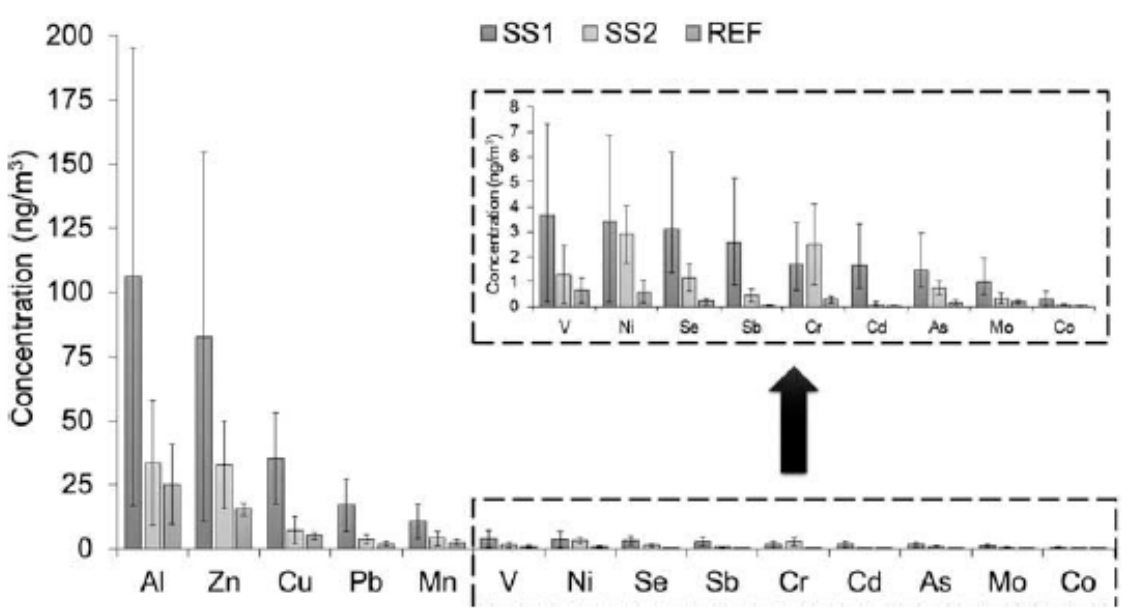

FIGURE 3. Concentration of $\mathrm{PM}_{10}$-bound trace elements $\left(\mathrm{ng} / \mathrm{m}^{3}\right.$ ) in ambient air at SS1 (urban site), SS2 (suburban site), and REF (reference site). 


\section{Trace Elements Associated With Fine (PM2.5) and Inhalable (PM10) Particles}

Figures 2 and 3 show the content (mean $\square$ \} SD) of the analyzed trace elements in $\mathrm{PM} 2.5$ and PM10 particles at the SS1 and SS2 (at REF only PM10 particles were monitored). Interestingly, the most abundant element in $\mathrm{PM} 2.5$ was $\mathrm{Zn}$, while in $\mathrm{PM} 10$ it was $\mathrm{Al}$. After $\mathrm{Al}$ and $\mathrm{Zn}$, the most abundant elements were $\mathrm{Cu}, \mathrm{Pb}$, and $\mathrm{Mn}$. Table 3 shows the ratios of the content of each trace element associated to $\mathrm{PM} 10$ and $\mathrm{PM} 2.5$. A ratio equal to 1 indicates that all trace elements are present in PM2.5. A ratio of 2 infers that the trace element is equally distributed between PM2.5 and "inhalable coarse particles" (i.e., particles with diameters between $2.5 \mu \mathrm{m}$ and $10 \mu \mathrm{m}$ ). Independently from the sampling site, most of the trace elements amounts in air were associated with PM2.5. The most important exceptions were $\mathrm{Al}$ and $\mathrm{Mn}$, elements that were predominantly associated with PM10 (PM10/PM2.5 ratio higher than 3).

Environmental aerosols toxicity is probably linked not only to increased PM mass, but also to variations in particle size, shape, and chemistry, particularly differences in the concentration of highly toxic elements (Cakmak et al., 2014; Chen and Lippmann, 2009; Satsangi et al., 2014). 
TABLE 2. Ratio Between the Trace Element Concentration $\left(\mathrm{ng} / \mathrm{m}^{3}\right)$ in Ambient Air at the Different Sampling Sites, as Measured in $\mathrm{PM}_{10}$

\begin{tabular}{lcrl}
\hline & \multicolumn{3}{l}{ Ratio } \\
\cline { 2 - 4 } Trace element & SS1/SS2 & SS1/REF & SS2/REF \\
\hline $\mathrm{Al}$ & 3.2 & 4.2 & 1.3 \\
$\mathrm{As}$ & 2.0 & 8.2 & 4.1 \\
$\mathrm{Cd}$ & 15.2 & 39.3 & 2.6 \\
$\mathrm{Co}$ & 3.3 & 5.5 & 1.7 \\
$\mathrm{Cr}$ & 0.7 & 5.7 & 8.5 \\
$\mathrm{Cu}$ & 5.0 & 7.0 & 1.4 \\
$\mathrm{Mn}$ & 2.7 & 4.5 & 1.6 \\
$\mathrm{Mo}$ & 2.8 & 4.9 & 1.7 \\
$\mathrm{Ni}$ & 1.2 & 5.8 & 4.9 \\
$\mathrm{~Pb}$ & 4.8 & 9.6 & 2.0 \\
$\mathrm{Se}$ & 2.6 & 13.1 & 5.0 \\
$\mathrm{Sb}$ & 5.8 & 48.0 & 8.3 \\
$\mathrm{~V}$ & 2.8 & 5.5 & 1.9 \\
$\mathrm{Zn}$ & 2.5 & 5.4 & 2.1 \\
\hline
\end{tabular}

Note. SS1, urban site; SS2, suburban site; REF, reference site.

TABLE 3. Ratio Between the PM10- and PM2.5-Bound Trace Element Concentration $\left(\mathrm{ng} / \mathrm{m}^{3}\right.$ ) in Ambient Air at SS1 (Urban Site) and SS2 (Suburban Site)

\begin{tabular}{lll}
\hline Trace element & $\begin{array}{l}\mathrm{SS} 1 \\
\left(\mathrm{PM}_{10} / \mathrm{PM}_{2.5}\right)\end{array}$ & $\begin{array}{l}\mathrm{SS} 2 \\
\left(\mathrm{PM}_{10} / \mathrm{PM}_{2.5}\right)\end{array}$ \\
\hline $\mathrm{Al}$ & 3.3 & 3.2 \\
$\mathrm{As}$ & 1.1 & 1.0 \\
$\mathrm{Cd}$ & 1.0 & 1.2 \\
$\mathrm{Co}$ & 1.5 & 2.3 \\
$\mathrm{Cr}$ & 1.3 & 1.1 \\
$\mathrm{Cu}$ & 2.1 & 1.8 \\
$\mathrm{Mn}$ & 3.2 & 2.6 \\
$\mathrm{Mo}$ & 2.0 & 1.6 \\
$\mathrm{Ni}$ & 1.7 & 1.4 \\
$\mathrm{~Pb}$ & 1.0 & 1.1 \\
$\mathrm{Se}$ & 1.1 & 1.3 \\
$\mathrm{Sb}$ & 1.0 & 1.1 \\
$\mathrm{~V}$ & 1.5 & 2.4 \\
$\mathrm{Zn}$ & 1.3 & 1.4 \\
\hline
\end{tabular}

\section{Enrichment Factor Analysis}

Enrichment factors close to 1 were observed for Al and Mn. Very high EFs ( $>1000)$ were obtained for Se, Cd, and Sb in both PM2.5 and PM10 at SS1 (Figure 4a). High EFs (>100) were also observed for $\mathrm{As}, \mathrm{Mo}, \mathrm{Pb}$, and $\mathrm{Zn}$ in both $\mathrm{PM} 2.5$ and $\mathrm{PM} 10$ at the same sampling site (SS1). At SS2, a similar trend was observed: high EF (>1000) for Sb and Se, followed by As, Cd, Mo, $\mathrm{Pb}$, and $\mathrm{Zn}$ (all with EF > 100) in both PM2.5 and PM10 (Figure 4b). These results indicate noncrustal sources for these trace elements in ambient air. As indicated previously, several industrial facilities, including a steel factory, power plant, refinery, and solid waste incineration plant, exist at PMA, and there is sufficient evidence that these facilities are important sources of Cd, Sb, Se, and As (González-Castanedo et al., 2014; Xu et al., 2011). Further, traffic-related 
emissions have also been recognized as one of the main sources of trace elements like $\mathrm{Pb}$ and $\mathrm{Zn}$ (Gunawardena et al., 2012) that also displayed high EF. In contrast, Al, Co, and Mn presented low EF, suggesting that crustal sources such as street dust are the predominant sources of these elements in the ambient air (Gugamsetty et al., 2012).

\section{Human Health Risk Assessment}

A human health risk assessment for PMbound trace elements was carried out. The pertinent values of CDI, RfD, HQ, SF, and ELCR for adults are given in Table 4. The mean concentration levels $(\mathrm{ng} / \mathrm{m} 3)$ of different trace elements were used for calculations.

The worst-case scenario (SS1) was selected for this risk assessment. As shown in Table 4, for adults, the level of noncarcinogenic risk (HI) was estimated to be $1.06 \times 10^{-3}$ for PM2.5 and $4.61 \times 10-3$ for PM10, and carcinogenic risk (sum of all ELCR) was estimated to be $1.14 \times 10$ -5 for PM2.5 and $5.58 \times 10-5$ for PM10. Based upon these findings, it can be concluded that the noncarcinogenic risk (indicated by both HQ and HI) falls well below acceptable levels $(<0.2$ for HQ and $<1$ for HI). In contrast, carcinogenic risk (indicated by ELCR), was found to be not negligible (i.e., $>1 \times 10-5$ ) (U.S. DOE, 1999). Carcinogenic risk was also estimated for SS2 and again observed to be not negligible. However, it needs to be pointed out that $\mathrm{Cr}$ was considered to be all in its hexavalent form $\left(\mathrm{Cr}^{+}\right)$in this assessment, which typically is not the case (Wilbur et al., 2012). The carcinogenic risk assessment performed here only considered PM-bound trace elements. Since other compounds such as PAH may also account for carcinogenic risks, a more comprehensive and detailed study is necessary for a complete risk assessment.
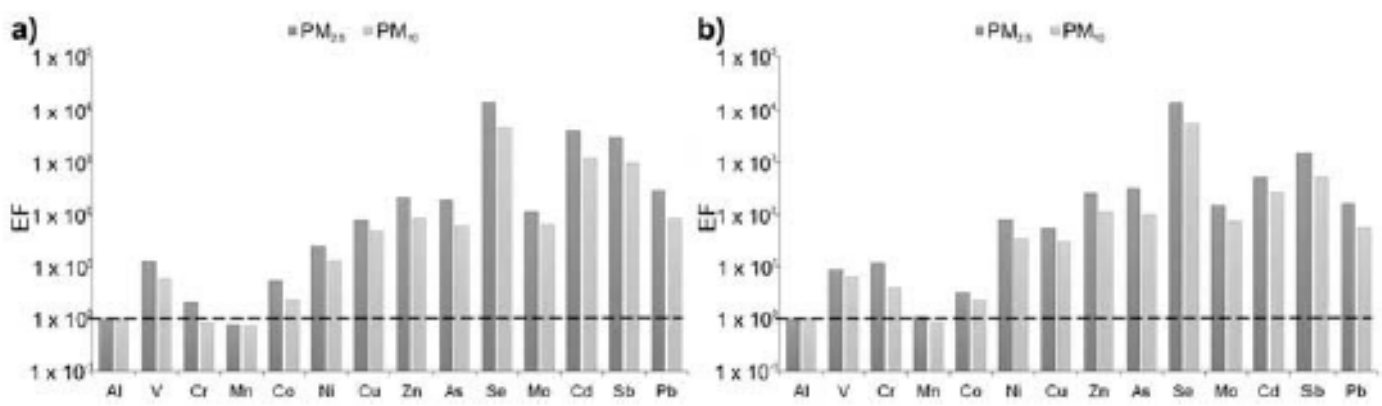

FIGURE 4. Enrichment factors (EF) of trace elements associated to (a) $\mathrm{PM}_{2.5}$ and (b) $\mathrm{PM}_{10}$. 
TABLE 4. Estimation of Human Health Risk for (a) $\mathrm{PM}_{2.5}$ and (b) $\mathrm{PM}_{10}$ at SS1

\begin{tabular}{|c|c|c|c|c|c|}
\hline Trace element & $\begin{array}{l}\text { CDI } \\
(\mathrm{mg} / \mathrm{kg} / \text { day })\end{array}$ & $\begin{array}{l}\text { RfD } \\
(\mathrm{mg} / \mathrm{kg} / \text { day })\end{array}$ & $\mathrm{HQ}$ & $\begin{array}{l}\mathrm{SF} \\
(\mathrm{mg} / \mathrm{kg} / \text { day })\end{array}$ & ELCR \\
\hline \multicolumn{6}{|l|}{ (a) $\mathrm{PM}_{2.5}$} \\
\hline \multicolumn{6}{|c|}{ Noncarcinogenic trace elements } \\
\hline $\mathrm{Al}$ & $43.3 \times 10^{-7}$ & $1.00 \times 10^{\circ}$ & $0.43 \times 10^{-5}$ & - & - \\
\hline $\mathrm{Cr}$ & $1.71 \times 10^{-7}$ & $3.00 \times 10^{-3}$ & $5.71 \times 10^{-5}$ & - & - \\
\hline Mn & $4.48 \times 10^{-7}$ & $1.40 \times 10^{-1}$ & $0.32 \times 10^{-5}$ & - & - \\
\hline Mo & $0.67 \times 10^{-7}$ & $5.00 \times 10^{-3}$ & $1.34 \times 10^{-5}$ & - & - \\
\hline $\mathrm{Se}$ & $3.96 \times 10^{-7}$ & $5.00 \times 10^{-3}$ & $7.93 \times 10^{-5}$ & - & - \\
\hline $\mathrm{Sb}$ & $3.35 \times 10^{-7}$ & $4.00 \times 10^{-4}$ & $83.7 \times 10^{-5}$ & - & - \\
\hline V & $3.27 \times 10^{-7}$ & $9.00 \times 10^{-3}$ & $3.63 \times 10^{-5}$ & - & - \\
\hline \multirow[t]{2}{*}{ Zn } & $83.2 \times 10^{-7}$ & $3.00 \times 10^{-1}$ & $2.77 \times 10^{-5}$ & - & - \\
\hline & & & $\Sigma=1.06 \times 10^{-3}$ & - & - \\
\hline \multicolumn{6}{|c|}{ Carcinogenic trace elements } \\
\hline As & $1.84 \times 10^{-7}$ & - & - & 15.1 & $2.77 \times 10^{-6}$ \\
\hline $\mathrm{Cd}$ & $2.26 \times 10^{-7}$ & - & - & 6.3 & $1.42 \times 10^{-6}$ \\
\hline $\mathrm{Cr}$ & $1.71 \times 10^{-7}$ & - & - & 41 & $7.06 \times 10^{-6}$ \\
\hline \multirow[t]{2}{*}{$\mathrm{Ni}$} & $2.70 \times 10^{-7}$ & - & - & 0.84 & $0.23 \times 10^{-6}$ \\
\hline & & & & & $\Sigma=1.14 \times 10^{-5}$ \\
\hline \multicolumn{6}{|l|}{ (b) $\mathrm{PM}_{10}$} \\
\hline \multicolumn{6}{|c|}{ Noncarcinogenic trace elements } \\
\hline $\mathrm{Al}$ & $56.5 \times 10^{-6}$ & $1.00 \times 10^{\circ}$ & $0.57 \times 10^{-4}$ & - & - \\
\hline $\mathrm{Cr}$ & $0.90 \times 10^{-6}$ & $3.00 \times 10^{-3}$ & $2.99 \times 10^{-4}$ & - & - \\
\hline $\mathrm{Mn}$ & $5.68 \times 10^{-6}$ & $1.40 \times 10^{-1}$ & $0.41 \times 10^{-4}$ & - & - \\
\hline Mo & $0.52 \times 10^{-6}$ & $5.00 \times 10^{-3}$ & $1.04 \times 10^{-4}$ & - & - \\
\hline Se & $1.65 \times 10^{-6}$ & $5.00 \times 10^{-3}$ & $3.30 \times 10^{-4}$ & - & - \\
\hline $\mathrm{Sb}$ & $1.37 \times 10^{-6}$ & $4.00 \times 10^{-4}$ & $34.2 \times 10^{-4}$ & - & - \\
\hline V & $1.95 \times 10^{-6}$ & $9.00 \times 10^{-3}$ & $2.16 \times 10^{-4}$ & - & - \\
\hline \multirow[t]{2}{*}{$\mathrm{Zn}$} & $44.0 \times 10^{-6}$ & $3.00 \times 10^{-1}$ & $1.47 \times 10^{-4}$ & - & - \\
\hline & & & $\Sigma=4.61 \times 10^{-3}$ & - & - \\
\hline \multicolumn{6}{|c|}{ Carcinogenic trace elements } \\
\hline As & $7.92 \times 10^{-7}$ & - & - & 15.1 & $1.20 \times 10^{-5}$ \\
\hline $\mathrm{Cd}$ & $8.82 \times 10^{-7}$ & - & - & 6.3 & $0.56 \times 10^{-5}$ \\
\hline $\mathrm{Cr}$ & $8.96 \times 10^{-6}$ & - & - & 41 & $3.67 \times 10^{-5}$ \\
\hline $\mathrm{Ni}$ & $1.83 \times 10^{-6}$ & - & - & 0.84 & $0.15 \times 10^{-5}$ \\
\hline
\end{tabular}

\section{CONCLUSIONS}

PMA ambient air quality was studied regarding several trace elements concentrations as measured bound to both PM2.5 and PM10.

Taking as reference EU standards, the air quality in the studied area may be regarded as good. The concentrations of almost all elements with the exception were $\mathrm{Cr}$ decreased from the urban to the suburban sampling site. Arsenic, $\mathrm{Cd}, \mathrm{Ni}, \mathrm{Pb}, \mathrm{Sb}, \mathrm{Se}, \mathrm{V}$, and $\mathrm{Zn}$ were mostly associated with PM2.5, suggesting that anthropogenic sources such as industry and road traffic are the main sources of these elements, which was further confirmed by high enrichment factors $(E F>100)$ obtained for $\mathrm{As}, \mathrm{Cd}, \mathrm{Pb}, \mathrm{Sb}, \mathrm{Se}$, and $\mathrm{Zn}$. A health risk assessment showed a negligible noncarcinogenic risk (HQ and HI well below 0.2 and 1, respectively), but a nonnegligible carcinogenic risk $(>1 \times 10-5)$ if all $\mathrm{Cr}$ in the ambient air is present as $\mathrm{Cr}(\mathrm{VI})$.

\section{FUNDING}

This work received financial support from the European Union (FEDER funds through COMPETE) and National Funds (FCT, Fundação para a Ciência e Tecnologia) through project PTDC/SAU-ESA/108871/2008 and project Pest-C/EQB/LA0006/2013. This work was also financially supported by CESPU, through project 01-GCQF-CICS-09.

\section{REFERENCES}

Beckerman, B. S., M. Jerrett, M. Finkelstein, P. Kanaroglou, J. R. Brook, M. A. Arian, 
M. R. Sears, D. Stieb, J. Balmes, and K. Chapman. 2012. The association between chronic exposure to traffic-related air pollution and ischemic heart disease. J. Toxicol. Environ. Health A 75: 402-411.

Bell, M. L., and HEI Health Review Committee. 2012. Assessment of the health impacts of particulate matter characteristics. Res. Rep. Health Effects Inst. 161: 5-38.

Cakmak, S., R. Dales, L. M. Kauri, M. Mahmud, K. Van Ryswyk, J. Vanos, L. Liu, P. Kumarathasan, E. Thomson, R. Vincent, and S. Weichenthal. 2014. Metal composition of fine particulate air pollution and acute changes in cardiorespiratory physiology. Environ. Pollut. 189: 208-214.

Chang, C.-C., C.-C. Kuo, S.-H. Liou, and C.- Y. Yang 2013. Fine particulate air pollution and hospital admissions for myocardial infarction in a subtropical city: Taipei, Taiwan. J. Toxicol. Environ. Health A 76: 440-448.

Chen, L. C., and M. Lippmann. 2009. Effects of metals within ambient air particulate matter (PM) on human health. Inhal. Toxicol. 21: 1-31.

Costa, S., J. Ferreira, C. Silveira, C. Costa, D. Lopes, H. Relvas, C. Borrego, P. Roebeling, A. I. Miranda and J. P. Texeira 2014. Integrating health on air quality assessment-Review report on health risks of two major European outdoor air pollutants: PM and NO2. J. Toxicol. Environ. Health B 17: 307-340.

Craig, L., J. R. Brook, Q. Chiotti, B. Croes, S. Gower, A. Hedley, D. Krewski, A. Krupnick, M. Krzyzanowski, M. D. Moran, W. Pennell, J. M. Samet, J. Schneider, J. Shortreed, and M. Williams. 2008. Air pollution and public health: A guidance document for risk managers. $J$. Toxicol. Environ. Health A 71: 588-698.

Franklin, M., P. Koutrakis, and J. Schwartz. 2008. The role of particle composition on the association between PM2.5 and mortality. Epidemiology 19: 680-689.

Ghio, A. J., M. S. Carraway, and M. C. Madden 2012. Composition of air pollution particles and oxidative stress in cells, tissues and living systems. J. Toxicol. Environ. Health B 15: $1-21$.

Ginsberg, G. L. 2012. Cadmium risk assessment in relation to background risk of chronic kidney disease. J. Toxicol. Environ. Health A 75: 374-390.

González-Castanedo, Y., T. Moreno, R. Fernández-Camacho, A. M. Sánchez de la Campa, A. Alastuey, X. Querol, and J. de la Rosa. 2014. Size distribution and chemical composition of particulate matter stack emissions in and around a copper smelter. Atmos. Environ. 98: 271-282.

Gugamsetty, B., H.Wei, C. N. Liu, A. Awasthi, S. C. Hsu, C. J. Tsai, G. D. Roam, Y. C. Wu, and C. F. Chen. 2012. Source characterization and apportionmentofPM10,PM2.5andPM0.1by using positive matrix factorization. Aerosol Air Qual. Res. 12: 476-491.

Gunawardena, J., P. Egodawatta, G. A. Ayoko, and A. Goonetilleke. 2012. Role of traffic in atmospheric accumulation of heavy metals and polycyclic aromatic hydrocarbons. Atmos. Environ. 54: 502-510.

Kabata-Pendias, A. 2011. Elements of group 13 (previously group IIIa). In Trace elements in soils and plants, 4th ed., 315-331. 
Philadelphia, PA: Taylor \& Francis Group. Krewski,D., andD. Rainham. 2007. Ambient air pollution and population health: Overview. J. Toxicol. Environ. Health A 70: 275-283.

Leeuw, F., and J. Horálek. 2009. Assessment of the health impacts of exposure to PM2.5 at a European level. European Topic Centre on Air and Climate Change (ETC/ACC) 21, The Netherlands, http://air-climate.eionet.europa.eu

Lippmann, M., L. C. Chen, T. Gordon, K. Ito, and G. D. Thurston. 2013. National Particle Component Toxicity (NPACT) Initiative: Integrated epidemiologic and toxicologic studies of the health effects of particulate matter components. Res. Rep. Health Effects Inst. 177: 5-13.

Needleman, H. 2004. Lead poisoning. Annu. Rev. Med. 55: 209-222. Peltier, R. E., S. I. Hsu, R. Lall, and M. Lippmann. 2009. Residual oil combustion: A major source of airborne nickel in New York City. J. Expos. Sci. Environ. Epidemiol. 19: 603-612.

Peltier, R. E., and M. Lippmann. 2010. Residual oil combustion: 2. Distributions of airborne nickel and vanadium within New York City. J. Expos. Sci. Environ. Epidemiol. 20: 342-350.

Pelucchi, C., E. Negri, S. Gallus, P. Boffetta, I. Tramacere, and C. La Vecchia. 2009. Longterm particulate matter exposure and mortality: A review of European epidemiological studies. $B M C$ Public Health 9: 453-461.

Samet, J., and D. Krewski. 2007. Health effects associated with exposure to air pollution. $J$. Toxicol. Environ. Health A 70: 227-242.

Sarmento, S., H. T. Wolterbeek, T. G. Verburg, and M. C. Freitas. 2008. Correlating element atmospheric deposition and cancer mortality in Portugal: Data handling and preliminary results. Environ. Pollut. 151: 341-351.

Satsangi, P. G., S. Yadav, A. S. Pipal, and N. Kumbhar. 2014. Characteristics of trace metals in fine (PM2.5) and inhalable (PM10) particles and its health risk assessment along with in-silico approach in indoor environment of India. Atmos. Environ. 92: 384-393. Schaumloffel, D. 2012. Nickel species: Analysis and toxic effects. J. Trace Elem. Med. Biol. 26: 1-6.

Shrey, K., A. Suchit, D. Deepika, K. Shruti, and R. Vibha. 2011. Air pollutants: The key stages in the pathway towards the development of cardiovascular disorders. Environ. Toxicol.

Pharmacol. 31: 1-9.

Sun, H. J., B. Rathinasabapathi, B. Wu, J. Luo, L. P. Pu, and L. Q. Ma. 2014. Arsenic and selenium toxicity and their interactive effects in humans. Environ. Int. 69: 148-158.

Taylor, S. R., and S. M. McLennan. 1985. The continental crust: Its composition and evolution. Oxford, UK: Blackwell Science.

Tsai, S.-S., and C.-Y. Yang. 2014. Fine particulate air pollution and hospital admissions for pneumonia in a subtropical city: Taipei, Taiwan. J. Toxicol. Environ. Health A 77: 192-201.

U.S. Department of Energy. 1999. Guidance for conducting risk assessments and related risk activities for the DOE-ORO Environmental Management Program, BJC/OR-271. http://rais.ornl.gov/homepage/bjc_or-271.pdf

U.S. Environmental Protection Agency. 2005. Standard operating procedure for the determination of metals in ambient particulate matter analyzed by inductively coupled plasma/mass spectrometry (ICP/MS). Office of Air Quality Planning and Standards, U.S. EPA, Research Triangle Park, NC. http://www.epa.gov/ttnamti1/files/ambient/airtox/metalsop.pdf. 
Vigotti, M. A., F. Chiaverini, P. Biagiola, and G. Rossi2007.Urbanair polutionandemergency visits for respiratory complaints in Pisa, Italy. J. Toxicol. Environ. Health A 70: 266-269.

World Health Organization. 2007. Health risks of heavy metals from long-range transboundary air pollution. Copenhagen, Joint WHO/Convention Task Force on the Health Aspects of Air Pollution, World Health Organization, Regional Office for Europe,

http://www.euro.who.int/_data/assets/pdf_file/0007/78649/E91044.pdf?ua=1

World Health Organization. 2013. Review of evidence on health aspects of air pollutionREVIHAAP Project: Technical report. Copenhagen, World Health Organization, Regional Office for Europe. http://www.euro.who.int/_data/assets/pdf_file/0004/ 193108/REVIHAAP_ Final-technical-reportfinal-version.pdf?ua=1.

World Health Organization. 2014. Burden of disease from the joint effects of household and ambient air pollution for 2012. Geneva, Switzerland: Public Health, Social and Environmental Determinants of Health Department.

Wilbur, S.,H. Abadin, M. Fay, D. Yu, B. Tencza, L. Ingerman, J. Klotzbach, and S. James. 2012. Toxicological profile for chromium. Atlanta, GA: Agency for Toxic Substances and Disease Registry (ATSDR), Toxicological Profiles.

Xu, M. H., D. X. Yu, H. Yao, X. W. Liu, and Y. Qiao. 2011. Coal combustion-generated aerosols: Formation and properties. Proc. Combust. Inst. 33: 1681-1697.

Zhang, Z. H., P. Y. K. Chau, H. K. Lai, and C. M. Wong. 2009. A review of effects of particulate matter-associated nickel and vanadium species on cardiovascular and respiratory systems. Int. J. Environ. Health Res. 19: 175-185. 